\title{
Peran Keterlibatan Ayah dalam Pengasuhan Bagi Perkembangan Kecerdasan Moral Anak
}

\author{
Dinda Septiani, Itto Nesyia Nasution \\ Fakultas Psikologi Universitas Abdurrab Pekanbaru \\ email: romanisti_dyenda@yahoo.com
}

\begin{abstract}
Abstrak
Penelitian ini bertujuan untuk mengetahui hubungan dan seberapa besar pengaruh peran keterlibatan ayah dalam pengasuhan terhadap perkembangan kecerdasan moral anak. Hasil penelitian ini nantinya bisa membuat para orangtua, terutama ayah dapat menyadari pentingnya sosok ayah dalam pengasuhan anak sehingga dapat memperbaiki dan mengembangkan peran ayah sejak anak usia dini agar dapat mencegah perilaku-perilaku negatif atau menyimpang yang akhir-akhir ini mulai marak terjadi pada generasi muda serta ayah tidak lagi hanya sebagai sosok pencari nafkah dalam keluarga. Penelitian ini menggunakan metode kuantitatif dengan menyebarkan skala kepada anak yang berada pada masa kanak-kanak akhir yang terdiri dari skala peran keterlibatan ayah dalam pengasuhan dan skala perkembangan kecerdasan moral. Alat ukur dianalisa secara statistik untuk melihat hubungan korelasinya. Hasil dari penelitian ini menunjukkan bahwa ada hubungan antara perkembangan kecerdasan moral anak dengan peran keterlibatan ayah dalam pengasuhan yang didasarkan pada nilai $p=0,000(p<0,05)$. Selain itu, sumbangan pengaruh keterlibatan ayah terhadap perkembangan kecerdasan moral anak sebesar $36 \%$. Hasil ini diharapkan bahwa sosok ayah sebaiknya dapat berperan langsung dalam pengasuhan anak-anak.
\end{abstract}

Kata kunci: kecerdasan moral anak, peran keterlibatan ayah

\section{The Role of Dad's Involvement in Parenting Development of Moral Intelligence of Children}

\begin{abstract}
This study aimed to determine relationship and how big the role influence for the father's involvement in parenting through the children's moral intelligence growth. The study outcome will be able to make the parents, especially the father can know that the importance of the father in parenting the children so can avoid and grow the father' role when early childhood so can avoid the negative or afield behavior which is lately viral on the young generation and then the fatheris not only as the lively fool seeker in his family. This study used the quantitative method by spreading the scale for the children which was the late childhood which was according to the father's involvement role scale in parenting and moral intelligence growth scale. The measuring equipment was analyzed as statistically to view the correlated relationship. Outcome of the study showed that existence of the relationship between the children's moral intelligence growth and father's involvement role in parenting which was based on the value $p=$ $0,000(p<0,05)$. Besides that, the contribution for the father's involvement influence through the children's moral intelligence growht was a big as $36 \%$. This outcome is hopeful that the father should be able to have a role directly in parenting the children.
\end{abstract}

Keywords: children's moral intelligence, father's involvement role

\section{Pendahuluan}

Orangtua selalu menginginkan anakanaknya tumbuh menjadi anak yang cerdas. Hal ini membuat orang tua menyiapkan kursus privat bagi anak di luar aktivitas sekolah. Sayangnya, usaha tersebut umumnya tertujukan semata pada keterampilan dan kecerdasan akal serta menomorduakan pendidikan karak- ter. Bukan mustahil generasi masyarakat saat ini dan yang akan datang akan dibanjiri orangorang cerdas dengan pengetahuan segudang namun memiliki kualitas moral yang rendah (Hidayati, Kaloeti \& Karyono, 2011).

Hal ini terbukti pada tahun-tahun terakhir, anak tidak lagi menjadi korban melainkan pelaku peristiwa tidak bermoral. Banyak sekali terjadi kasus-kasus kriminalitas dan 
kenakalan yang dilakukan oleh anak-anak (Komnas PA, dalam Liputan6.com, 2015). Rendahnya kualitas moral anak akan membahayakan masa depan terutama dalam era modernisasi sekarang ini (Afrianti \& Ruqoyah, 2012)

Komisi Nasional Perlindungan Anak (Liputan6.com, 2015) mencatat kasus kriminalitas yang dilakukan anak terus meningkat setiap tahunnya. Pada tahun 2014 sekitar $26 \%$ kenaikan dari tahun lalu, anak dilaporkan sebagai pelaku kekerasan, sedangkan tahun ini naik $18 \%$. Selain itu, berdasarkan Pusat Data Anak Berhadapan dengan Hukum (ABDH), sepanjang 2014 di Indonesia sedikitnya sekitar 2.879 anak melakukan tindak kekerasan mulai rentang usia $6-14$ tahun. Jumlah ini meliputi kejahatan seperti kekerasan pada anak lain, pencurian, narkoba, tawuran, pembunuhan dan pelecehan seksual.

Perkembangan moral tidak bisa dijauhkan dari rentang masa anak-anak. Moral tidak berkembang dengan sendirinya, tetapi harus diajarkan. Semakin dini moral diajarkan maka semakin besar kapasitas anak mencapai karakter yang solid, yaitu growing to think, believe, and act morally (Santrock, 2007). Piaget (dalam Santrock, 2007) menjelaskan bahwa pemahaman anak mengenai moral sudah muncul sejak usia 4 tahun. Kualitas moral tinggi dibutuhkan untuk membuat anak sukses dalam kehidupan di rumah maupun di lingkungan. Anak yang memiliki kualitas moral tinggi dapat dikatakan anak cerdas secara moral (Borba, 2008).

Kecerdasan moral didefinisikan oleh

Borba (2008) sebagai kemampuan untuk memahami benar dan salah dan pendirian yang kuat untuk berpikir dan berperilaku sesuai dengan nilai moral. Adapun aspek kecerdasan moral pada anak meliputi empati, nurani, kontrol diri, rasa hormat, baik budi, toleran dan adil. Selain itu, menurut Santrock (2007) perkembangan moral (moral development) berkaitan dengan aturan dan konvensi tentang apa yang seharusnya dilakukan oleh individu dalam interaksinya dengan orang lain.

Adapun faktor-faktor yang mempengaruhi keterlibatan ayah dikemukakan oleh Andayani \& Koentjoro (2004) Faktor yang mempengaruhi kecerdasan moral anak menurut (Berns dalam Borba, 2008), yaitu: situasi, individu (temperamen, kontrol diri, harga diri, umur, pendidikan, dan interaksi sosial), dan sosial (keluarga, teman sebaya, sekolah, media massa dan masyarakat).

Kecerdasan moral dibangun sejak dini dengan bantuan keluarga terutama orang tua. Orang tua memberi pengaruh langsung pada anak untuk memberikan contoh serta membimbing dan menjelaskan nilai atau aturan yang berlaku di masyarakat. Menurut Borba (2008), pengasuhan merupakan hal penting dalam mempengaruhi kepribadian anak. Orangtua memiliki peran berbeda dalam mengasuh anak. Ibu berperan besar pada perawatan anak, sedangkan ayah berperan pada aktivitas yang berhubungan dengan pembentukan pribadi anak.

Kenyataannya di lapangan, mendidik dan membesarkan anak lebih dibebankan kepada ibu, sedangkan ayah hanya bertugas mencukupi kebutuhan ekonomi keluarga, sehingga tidak ikut mengasuh, mendidik dan memenuhi kebutuhan kasih sayang anak. Padahal kualitas pengasuhan ibu atau ayah harus disejajarkan karena pengalaman yang dialami bersama ayah, akan mempengaruhi seorang anak hingga dewasa nantinya (Setyawati \& Rahardjo, 2015).

Indonesia merupakan salah satu negara yang mayoritas penduduknya menganut budaya patriarki, dimana peran laki-laki lebih banyak pada aspek publik, sementara perempuan pada aspek domestik. Oleh sebab itu, Indonesia didaulat sebagai fatherless country, negara tanpa keberadaan ayah secara psikologis karena minimnya peran ayah terhadap pendidikan keluarga (Kamila \& Mukhlis, 2013). Akibatnya anak-anak mengalami krisis father hunger, yang kemudian berdampak hilangnya rasa berani dan rasa percaya diri dalam dirinya. Selama ini studi-studi perkembangan anak telah mengupas tentang peranan ibu secara luas dan mendalam, sayangnya peran ayah seakan diabaikan (Formoso, dkk, 2007). Lamb (dalam Setyawati \& Rahardjo, 2015) mengungkapkan bahwa mengabaikan peran ayah sama saja dengan membiarkan terjadinya bias dalam perkembangan anak.

Keterlibatan ayah dalam pengasuhan merupakan hal yang sangat penting. Keterlibatan ayah dalam pengasuhan adalah suatu partisipasi aktif melibatkan fisik, afektif, dan kognitif dalam proses interaksi antara ayah 
dan anak yang memiliki fungsi endowment (mengakui anak sebagai pribadi), protection (melindungi anak dari sumber-sumber bahaya potensial dan berkontribusi pada pengambilan keputusan yang berpengaruh terhadap kesejahteraan anak), provinsion (memastikan kebutuhan material anak), formation (aktivitas bersosialisasi seperti pendisiplinan, pengajaran, dan perhatian) yang merepresentasikan peran ayah sebagai pelaksana dan pendorong bagi pembentukan dalam perkembangan anak (Berns, 2007).

Berns (2007) mengemukakan bahwa konsep keterlibatan ayah lebih dari sekedar melakukan interaksi positif dengan anak-anak mereka, tetapi juga memperhatikan perkembangan anak, terlihat dekat dengan nyaman, serta dapat memahami dan menerima anakanak mereka. Keterlibatan ayah mencakup empat area perkembangan anak yaitu, elemen fisik, sosial, spiritual, intelektual, dan mengandung unsur afektif (Grant dalam Andayani \& Koentjoro, 2004).

Penelitian dilakukan oleh Goleman (dalam Khayati, 2012) menunjukkan bahwa anak-anak yang hidup tanpa ayah mengalami permasalahan fisik dan psikologi seperti depresi, nilai akademik menurun, dan beberapa permasalahan lain berkaitan pergaulan. Selain itu, menurut Nangle, dkk (2003) keterlibatan ayah dalam pengasuhan memberikan dampak positif pada seluruh aspek perkembangan anak yaitu kognitif, intelektual dan pencapaian prestasi, emosi, sosial, peran jenis, moral, dan penurunan perkembangan anak yang negatif.

Gottman \& DeClaire (dalam Andayani \& Koentjoro, 2004) mengemukakan bahwa keterlibatan ayah akan mengembangkan kemampuan anak untuk berempati, penuh kasih sayang dan perhatian, serta hubungan sosial yang lebih baik. Selain itu, akan menyebabkan terbentuknya identitas gender yang sehat, perkembangan moral positif, serta penyesuaian diri positif pada anak. Kehangatan, bimbingan serta pengasuhan yang diberikan oleh ayah juga dapat memprediksi kematangan moral anak, yang diasosiasikan dengan perilaku prososial dan perilaku positif (Formoso, dkk, 2007).

Berangkat dari fenomena dan pentingnya keterlibatan ayah seperti yang telah dikemukakan diatas, maka peneliti tertarik untuk melakukan penelitian mengenai kecerdasan moral anak yaitu kemampuan mereka memahami benar dan salah serta dapat berperilaku sesuai nilai moral yang dihubungkan dengan peran keterlibatan ayah. Hipotesa dalam penelitian ini adalah ada hubungan antara peran keterlibatan ayah dalam pengasuhan bagi perkembangan kecerdasan moral anak.

Adapun tujuan dari penelitian ini adalah untuk mengetahui hubungan peran keterlibatan ayah dalam pengasuhan terhadap perkembangan kecerdasan moral anak serta berapa besar pengaruh yang diberikan. Sedangkan manfaatnya diharapkan bisa membuat orangtua, terutama ayah dapat menyadari pentingnya sosok ayah dalam pengasuhan anak sehingga dapat berperan sejak dini dalam mengasuh anak agar dapat mencegah perilaku negatif yang akhir-akhir ini mulai marak terjadi pada generasi muda.

\section{Metode}

Penelitian ini merupakan penelitian korelasi untuk melihat hubungan antara peran keterlibatan ayah dalam pengasuhan bagi perkembangan kecerdasan moral anak.Variabel dalam penelitian ini yaitu variabel $Y$ (tergantung) adalah kecerdasan moral dan variabel X (variabel bebas) adalah keterlibatan ayah dalam pengasuhan.

\section{Parstisipan}

Subjek dalam penelitian ini adalah anak yang berada pada masa kanak-kanak akhir berusia 10-12 tahun yang berjumlah 100 orang yang berada di Pekanbaru. Hal ini seperti yang dikemukakan oleh Piaget (dalam Santrock, 2007), bahwa anak-anak yang berada pada usia 10 hingga 11 tahun telah memiliki suatu kesadaran akan perasaan-perasaan orang lain dan dapat tersakiti ataupun merasa kecewa atas apa yang dilakukan oleh individu tersebut. Adapun metode pengambilan sampel yang akan digunakan adalah incidental sampling yaitu teknik pengambilan sampel berdasarkan kebetulan/incidental bertemu dengan peneliti dapat digunakan sebagai sampel, bila dipandang orang yang kebetulan ditemui itu cocok sebagai sumber data (Sugiyono, 2013). 


\section{Pengukuran}

Pengambilan data dalam penelitian ini dilakukan dengan menyebarkan skala yang terdiri dari skala keterlibatan peran ayah yang peneliti susun berdasarkan aspek-aspek keterlibatan ayah dalam pengasuhan oleh Lamb, dkk (dalam McBridge, Schoppe dan Rane, 2002) yaitu paternal engagement, paternal accessibility dan paternal responsibility serta skala kecerdasan moral yang peneliti susun berdasarkan aspek-aspek kecerdasan moral oleh Borba (2008) yaitu empati, nurani, kontrol diri, rasa hormat, baik budi, toleran dan adil. Skala yang telah peneliti susun ini kemudian diujicobakan kepada 30 anak. Berdasarkan data ujicoba yang diperoleh kemudian peneliti melakukan uji validitas dengan cara analisis aitem atau butir dan validitas isi. Selain itu, diperoleh juga nilai reliabilitas alat ukurnya sebesar 0, 959 untuk skala keterlibatan ayah dan 0,880 untuk skala kecerdasan moral.
Hal ini berarti ada hubungan antara perkembangan kecerdasan moral anak dengan peran keterlibatan ayah dalam pengasuhan. Selain itu, terdapat juga nilai korelasi ( $r$ ) sebesar : 0,602, yang artinya hubungannya cukup tinggi.

Setelah melihat hubungan antara dua variabel ini, penelitian ini juga ingin mengetahui seberapa besar pengaruh peran keterlibatan ayah dalam pengasuhan terhadap perkembangan kecerdasan moral anak. Analisa statistik menunjukkan nilai R2 yaitu 0,362 . Hal ini menunjukkan pengaruh peran keterlibatan ayah dalam pengasuhan terhadap perkembangan kecerdasan moral anak sebesar $36 \%$.

Adapun untuk kategorisasi gambaran data subjek skala peran keterlibatan ayah, peneliti menggunakan rumus kategorisasi skor tiga tingkat yaitu sebagai berikut:

\section{Hasil}

Berdasarkan analisa statistik menggunakan uji korelasi pearson product moment, diperoleh nilai signifikansi $p=0,000(p<0,05)$.

Tabel 1. Rumus Kategorisasi skor

\begin{tabular}{cl}
\hline Rumus & Kategori \\
\hline$X<(\mu-1,0 \sigma)$ & Rendah \\
$(\mu-1,0 \sigma) \leq X<(\mu+1,0 \sigma)$ & Sedang \\
$(\mu+1,0 \sigma) \leq X$ & Tinggi \\
\hline
\end{tabular}

Sumber: Azwar (2011)

Tinggi $\quad: X \geq(72,5+1.14,5)=X \geq 87$

Sedang $\quad:(72,5-1.14,5) \leq X<$

$(72,5+1.14,5)=58 \leq X<87$

Rendah
Berdasarkan rumus diatas maka diperoleh kategorisasi peran keterlibatan ayah sebagai berikut:

Tabel 2. Kategorisasi peran keterlibatan ayah

\begin{tabular}{lll}
\hline Kategori & frekuensi & Persentase \\
\hline Tinggi & 11 & $11 \%$ \\
Sedang & 27 & $27 \%$ \\
Rendah & 62 & $62 \%$ \\
\hline Jumlah & $\mathbf{1 0 0}$ & $\mathbf{1 0 0 \%}$ \\
\hline
\end{tabular}


Berdasarkan tabel di atas, maka dapat dilihat bahwa sebagian besar subjek penelitian merasa bahwa peran keterlibatan ayah dalam pengasuhan tergolong rendah yaitu $62 \%$. Sedangkan yang merasa peran ayah dalam pengasuhan tinggi hanya sekitar $11 \%$.

\section{Pembahasan}

Hasil penelitian menunjukkan bahwa ada hubungan antara perkembangan kecerdasan moral anak dengan peran keterlibatan ayah dalam pengasuhan. Hal ini sesuai dengan Hurlock (2009) yang mengatakan adapun aspek yang mempengaruhi perilaku moral adalah pemahaman tentang moral secara keseluruhan. Seorang anak mendapatkan pemahaman moral ini dengan belajar dari orangtuanya (orang terdekatnya). Jika hal ini melalui proses yang baik maka mereka akan tumbuh sebagai anak yang berperilaku sesuai aturan dan norma yang berlaku. Oleh karena itu, nilai moral menjadi penting diajarkan sejak awal kehidupan.

Penelitian yang dilakukan oleh Lamb (2010) yang menyatakan persepsi tentang peran ayah yang terlibat dalam pengasuhan dapat berpengaruh terhadap keseluruhan perkembangan sosial, emosional, moral dan prestasi akademik anak. Senada dengan pendapat tersebut, Berns (2007) menyatakan bahwa keterlibatan ayah penting bagi perkembangan pribadi anak, baik sosial, emosional maupun intelektualnya. Pada diri anak akan tumbuh motivasi, kesadaran diri, identitas serta kekuatan dan kemampuan yang nantinya akan memberi peluang untuk perkembangan emosinya.

Berdasarkan penelitian yang dilakukan oleh Gluecks (Hurlock, 2009), menemukan bahwa kenakalan remaja bukan fenomena baru dari masa remaja melainkan suatu lanjutan dari perilaku asosial yang dimulai pada masa kanak-kanak. Hal ini berhubungan erat dengan pengasuhan orangtua khususnya ayah menjadi sangat penting bagi perilaku moral anak. Seorang anak yang mendapatkan pengasuhan yang baik akan lebih mudah menyesuaikan diri dengan aturan dan norma di lingkungan.

\section{Kesimpulan}

Hasil penelitian menunjukkan bahwa ada hubungan antara perkembangan kecerdasan moral anak dengan peran keterlibatan ayah dalam pengasuhan.. Selain itu, dari hasil penelitian juga terlihat bahwa subjek yang merasa bahwa peran keterlibatan ayah dalam pengasuhan tergolong rendah yaitu sebanyak $62 \%$, sedangkan yang merasa peran ayah dalam pengasuhan tinggi hanya sekitar $11 \%$. Saran dalam penelitian ini adalah dapat menambah kelengkapan data dari pihak sekolah sehingga data tidak hanya dari anak dan bisa di cross check. Selain itu dengan hasil yang diperoleh diharapkan kepada para ayah untuk dapat terlibat dalam pengasuhan, dapat memperhatikan perkembangan serta menjadi sosok yang dapat dicontoh sehingga moral anak dapat berkembang dengan baik.

\section{Daftar Pustaka}

Afrianti, D., \& Ruqoyah, S. (2012). Kasus Kriminal Dilakukan Anak-anak. Diterima tanggal 20 Februari 2016. Dari http://metro.news.viva.co.id/ news/read/312779-2-008-kasuskriminal dilakukan-anak-anak.

Andayani, B. \& Koentjoro, (2004). Peran Ayah Menuju Coparenting. Sepanjang: CV. Citra Media.

Berns, R.M. (2007). Child, Family, School, Community : Socialization and Support. United States of America : Thomson Learning, Inc.

Borba, M. (2008). Membangun Kecerdasan Moral: tujuh kebajikan utama agar anak bermoral tinggi. Jakarta: PT. Gramedia Pustaka Utama.

Formoso, D., dkk. (2007). Interparental relations, maternal employment, and fathering in Mexican American families. Journal of Marriage and Family, 69, 26-39.

Hidayati, F., Kaloeti, D., \& Karyono. (2011). Peran Ayah dalam Pengasuhan Anak. Jurnal Psikologi UNDIP. Fakultas Psikologi Universitas Diponegoro. Semarang, 9 (1), 1-10.

Hurlock, E.B. (2009). Psikologi Perkembangan : Suatu Pendekatan Sepanjang Rentang Kehidupan. 
Jakarta : Penerbit Erlangga.

Kamila, I., \& Mukhlis. (2013). Perbedaan harga diri remaja ditinjau dari keberadaan ayah. Jurnal Psikologi, 9 (2), 100-111.

Khayati, N.L. (2012). Hubungan keterlibatan ayah dalam pengasuhan dan motivasi berprestasi pada siswa MTS Wathaniyah Islamiyah Kebumen. Proceeding Nasional II PPI, 12 (2), 30-238.

Lamb, M. E. (2010). The Role of Father in Child Deaelopment Fifth edition. New York: John Willey \& Sons Inc.

Liputan6.com. (2015). Pelaku Kekerasan anak meningkat. Diterima tanggal 25 Februari 2016. Dari m.liputan6.com/ news/read/21544228/komnaspa-pelaku-kekerasan-anakmeningkat-tahun-2015.

McBride, B.A., Schoppe, S.J., \& Rane, T.R. (2002). Child characteristic, parenting stress and parental involvement. Journal of Marriage and the family, 64 (3), 998-1011.

Nangle, S.M., Kelley, M.L., Fals, W., \& Levant, R.F. (2003). Work and Family Variables as relatetd to paternal engagement, responsibility and accessibility in dual earner couples with young children. Journal Fathering, 14 (2), 200-219.

Palkovitz, R. (2002). Involved fathering and child development: Advancing our understanding of good fathering. Handbook of father involvement: Multidisicplinary perspectives. New Jersey: Lawrence Erlbaum Associates.

Santrock, J.W. (2007). Child Development. 11th edition. New York : McGraw-Hill Companies, Inc.

Setyawati, \& Rahardjo, P. (2015). Keterlibatan ayah serta faktor-faktor yang berpengaruh dalam pengasuhan seksualitas sebagai upaya pencegahan perilaku seks pranikah remaja di Purwokerto. Jurnal Psikologi. Fakultas Psikologi Universitas Muhammadiyah Purwokerto, 3 (2), 35-55.

Sugiyono. (2013). Metode Penelitian Kuantitatif Kualitatif dan $R$ \& $D$. Bandung: Alfabeta. 